\title{
MENGUKUR TINGKAT KEPUASAN MAHASISWA DALAM PEMBELAJARAN DENGAN MEMNGGUNKAN SISTEM PAKAR (Studi Kasus: Mahasiswa Teknik Informatika)
}

\author{
Dede Abdurahman ${ }^{1}$, Tri Perga Prasetyo ${ }^{2}$ \\ Teknik Informatika, Fakultas Teknik Universitas Majalengka \\ email: dedeab2008@yahoo.com ${ }^{1}$, triferga.prasetyo@gmail.com ${ }^{2}$
}

\section{ABSTRACT}

In the development of an information system needs good planning so that the system can run develop information in accordance with the needs buisness. So that date and information generated can be qualified, consistent and not separately. Steps to obtain such information or data which includes:

1. Planning which describes the planning strategy.

2. Develop a method of Enterprise Architecture Planning (EAP) for the planning of the development of this system.

Software that supports the task of making the manufacture of this expert system using:

1. notepad ++

2. using the programming language $P H P$

3. Its database using $M y S Q L$

4. The engine of PHP is using Apache Tried.

The results of this task in the form of a web-based program, the program aims to measure the level of satisfaction of the students are learning in class or delivered by the lecturer.

Keywords: Introduction to Artificial Intelligence, Expert Systems Measuring Satisfaction Students in Learningconcerned.

\section{PENDAHULUAN}

Semakin berkembangnya teknologi informasi pada saat ini membuat kehidupan kita semakin mudah, salah satunya semakin pesatnya penelitian dan evolusi Artificial intelligent atau kecerdasan buatan, yang membantu dalam berbagai bidang kehidupan, salah satunya sistem pakar yang mampu menyelesaikan suatu masalah atau hanya sekedar mencari informasi berkualitas yang sebenarnya hanya dapat diperoleh dengan bantuan para ahli di bidangnya. Dalam penyusunannya, sistem pakar mengkombinasikan kaidah-kaidah penarikan kesimpulan (Inference rules) dengan basis pengetahuan tertentu yang diberikan oleh satu atau lebih pakar dalam bidang tertentu. Kombinasi dari kedua hal tersebut disimpan dalam komputer, yang selanjutnya digunakan dalam proses pengambilan keputusan untuk penyelesaian masalah tertentu (Saputra, 2013).

Pengajaran adalah suatu sistem. Artinya keseluruhan yang terdiri dari komponenkomponen yang berinteraksi antara satu dengan yang lainnya secara keseluruhan untuk mencapai tujuan pengajaran yang telah ditetapkan sebelumnya. Komponen-komponen tersebut meliputi, tujuan pendidikan, peserta didik, pendidik, bahan atau materi pelajaran, pendekatan dan metode, media atau alat, sumber belajar, evaluasi. Pada dasarnya, proses pengajaran dapat terselenggara secara lancar, efisien, dan efektif berkat adanya interaksi yang positif, konstruktif, dan produktif antara berbagai komponen yang terkandung di dalam system pengajaran tersebut. Salah satu cara yang dapat dilakukan untuk mengetahui hasil yang telah dicapai oleh pendidik dalam proses pembelajaran adalah melalui evaluasi (Slameto, 2010).

Menghadapi laju perkembangan teknologi yang begitu pesat, setiap lembaga termasuk lembaga pendidikan seperti Universitas Majalengka dituntut untuk tanggap terhadap perubahan-perubahan yang terjadi di lingkungan baik yang terkait dengan internal maupun lingkungan eksternalnya. Perlu adanya strategi-strategi khusus yang harus dilakukan agar lembaga tersebut dapat bertahan dan bahkan dapat meningkatkan prestasi dalam akademiknya. Oleh sebab itu, pihak lembaga 
harus lebih proaktif dan terus melakukan perbaikan dalam segala hal. Contohnya dengan meningkatkan kinerja pendidik dalam pembelajaran terhadap Mahasiswanya.

Karena melihat hal tersebut, penulis mendapatkan ide untuk membuat sistem pakar dengan menggunakan teknologi komputerisasi aplikasi berbasis web dalam pengukuran tingkat kepuasan pembelajaran mereka. Web merupakan jenis layanan yang paling populer dikalangan pengguna internet. Setiap dokumen ditulis menggunakan suatu format standar yang disebut Hypertext Markup Language (HTML) (Supriyanto, 2005: 340).

\section{TINJAUAN TEORI \\ 2.1. Landasan Teori \\ 2.1.1. Kecerdasan Buatan}

Kecerdasan Buatan atau Artificial Intelligence merupakan salah satu bagian ilmukomputer yang membuat agar mesin (komputer) dapat melakukan pekerjaan sepertidan sebaik yang dilakukan manusia. Pada awal diciptakannya, komputer hanya difungsikan sebagai alat hitung saja. Namun seiring dengan perkembanganjaman, maka peran komputer semakin mendominasi kehidupan umat manusia.

Komputer tidak lagi hanya digunakan sebagai alat hitung, lebih dari itu, computer diharapkan untuk dapat diberdayakan untuk mengerjakan sesuatu yang bisa dikerjakan oleh manusia (Ari Minartiningtyas, 2013).

Manusia bisa menjadi pandai dalam menyelesaikan segala permasalahan di dunia ini karena manusia mempunyai pengetahuan dan pengalaman. Pengetahuan diperoleh dari cara mempelajarinya. Semakin banyak bekal pengetahuan yang dimiliki oleh seseorang tentu saja diharapkan akan lebih mampu dalam menyelesaikan permasalahan. Namun bekal pengetahuan saja tidak cukup, manusia juga diberi akal untuk melakukan penalaran, mengambil kesimpulan berdasarkan pengetahuan dan pengalaman yang mereka miliki. Tanpa memiliki kemampuan untuk menalar dengan baik, manusia dengan segudang pengalaman dan pengetahuan tidak akan dapat menyelesaikan masalah dengan baik. Demikian juga dengan kemampuan menalar yang sangat baik, namun tanpa dibekali pengetahuan dan pengalaman yang memadai, manusia juga tidak akan bisa menyelesaikan masalah dengan baik (Kusumadewi, 2003).
Dengan adanya kecerdasan buatan, diharapkan tidak menutup kemungkinan hanya dengan data pengetahuan yang terbatas, sebuah komputer dapat berpikir seperti manusia dalam menghadapi masalah (Ari Minartiningtyas, 2013).

\subsubsection{Sistem Pakar}

Sistem pakar adalah program komputer yang menggunakan pengetahuan pakar untuk mencapai tingkat kinerja yang tinggi pada area yang sempit (Waterman, 1986).Secara umum, sistem pakar adalah sistem yang berusaha mengadopsi pengetahuan manusia ke komputer, agar komputer dapat menyelesaikan masalah seperti yang biasa dilakukan oleh para ahli (Kusumadewi, 2003:109).

Pakar yang dimaksud disini adalah orang yang mempunyai keahlian khusus yang dapat menyelesaikan masalah yang tidak dapat diselesaikan orang awam. Sebagai contoh, dokter adalah seorang pakar yang mampu mendiagnosis penyakit yang diderita pasien serta dapat memberikan penatalaksanaan suatu penyakit. Contoh yang lain, montir adalah seorang yang mempunyai keahlian dan pengalaman dalam menyelesaikan kerusakan mesin motor/mobil; psikolog adalah orang yang ahli dalam memahami kepribadian seseorang, dan lain-lain (Tambunan,2011).

\subsubsection{Metode Forward Chaining}

Secara umum dalam inferensi runut maju (Forward Chaining) aturan (rule) akan diuji satu persatu dalam urutan tertentu. Saat tiap aturan diuji, sistem akan mengevaluasi apakah kondisi benar atau salah. Dengan kata lain, penalaran dimulai dari fakta terlebih dahulu untuk menguji hipotesis. Runut maju merupakan metode pencarian yang memulai proses pencarian dari sekumpulan data atau fakta, dari fakta-fakta tersebut dicari suatu kesimpulan yang menjadi solusi dari permasalahan yang dihadapi. Mesin inferensi mencari kaidah-kaidah dalam basis pengetahuan yang premisnya sesuai dengan fakta-fakta tersebut, kemudian dari aturanaturan tersebut diperoleh suatu kesimpulan. Runut maju memulai proses pencarian dengan data sehingga strategi ini disebut juga datadriven.(Yunanto, 2003)

\subsubsection{Metode Backward Chaining}

Runut balik merupakan metode pencarian yang arahnya kebalikan dari runut maju. Proses 
pencarian dimulai dari tujuan, yaitu kesimpulan yang menjadi solusi dari permasalahan yang dihadapi. Mesin inferensi mencari aturan-aturan dalam basis pengetahuan yang kesimpulannya merupakan solusi yang ingin dicapai, kemudian dari aturan-aturan yang diperoleh, masingmasing kesimpulan dirunut balik jalur yang mengarah ke kesimpulan tersebut. Jika informasi-informasi atau nilai dari atributatribut yang mengarah ke kesimpulan tersebut sesuai dengan data yang diberikan maka kesimpulan tersebut merupakan solusi yang dicari, jika tidak sesuai maka kesimpulan tersebut bukan merupakan solusi yang dicari. Runut balik memulai proses pencarian dengan suatu tujuan sehingga strategi ini disebut juga goal-driven. (Yunanto, 2003).

\subsubsection{Kepuasan}

Kepuasan menurut Kotler adalah tingkat perasaan seseorang setelah membandingkan kinerja atau hasil dengan harapannya (Tjiptono, 2000 : 90). Suatu pelayanan memiliki potensi untuk memenuhi atau tidak memenuhi harapan pelanggan. Suatu jasa dianggap memuaskan jika memiliki kualitas. Kualitas merupakan suatu kondisi dinamis yang berhubungan dengan jasa, proses, dan lingkungan yang memenuhi atau melebihi harapan. Penilaian kualitas pelayanan atau jasa dapat diukur dengan dua variable, yaitu jasa yang dirasakan (perceived service) dan jasa yang diharapkan (expected service). Kepuasan dapat dilihat dari kesesuaianantara harapan dengan apa yang didapat dari suatu pelayanan (Tjiptono, 2000 : 52).

\subsubsection{World Wide Web (WWW)}

Layanan $W W W$ atau web merupakan jenis layanan yang paling popular dikalangan pengguna internet. Web tidak hanya berfungsi sebagai media untuk mencari informasi, tetapi web sudah banyak digunakan secara komersial oleh hampir semua perusahaan-perusahaan di seluruh dunia untuk mengiklankan usaha mereka. Setiap dokumen yang ditulis menggunakan suatu format standar yang disebut $H T M L$. Dokumen yang ditransfer antar Web Sever menggunakan suatu protokol yang disebut Hypertext Transfer Protocol (HTTP).Web saat ini telah semakin dinamis, interaktif dan cerdas dengan bahasa pemrograman yang dikembangkan untuk menutupi kekurangan yang terdapat pada $H T M L$, sebagai bahasa standar untuk web. Jika dulu suatu web hanya dapat menyajikan informasi, saat ini suatu web telah dapat berinteraksi dengan pengguna melalui pengisian form, validasi input atau transaksi online. Untuk mengakses web, dapat digunakan web browser seperti netscape navigator, internet explorer, neo-planet, mosaic dan lain sebagainya. (Supriyanto, 2005: 340)

\subsubsection{Pengenalan PHP}

Hypertext Processor (PHP) adalah bahasa pemograman web server-side yang bersifat open source. Php merupakan script yang terintegrasi dengan $H T M L$ dan berada pada server (sever side HTML embedded scripting). (Anhar, 2010: 3). PHP pertama kali dibuat dan diperkenalkan oleh Rasmus Lerdorf pada tahun 1995 menggunakan nama PHP/FI, generasi awal PHP/FI dibuat dari Perl yang waktu itu digunakan untuk kebutuhan pribadi saja. Pada tahun 1997 dikeluarkanlah PHP/FI versi 2.0, fungsi-fungsi pada PHP/FI ditulis dengan menggunakan bahasa C. PHP versi 3.0 diluncurkan oleh Andi Gutmans dan Zeev Suraski pada tahun yang sama dimana versi ini telah mendukung berbagai jenis database, protokol, dan API. Untuk menangani kelemahan versi 3.0 maka diluncurkanlah PHP versi 4 dan PHP versi 5, dimana PHP versi 5 ini dapat membuat file swf dan applet java. Versi ini diluncurkan pada tahun 2004. Fokus utamanya adalah mengoptimalkan penggunaan PHP untuk Object Oriented Produkming (OOP) (Anhar, 2010: 2). Menurut tim Litbang LPKBM MADCOMS Madiun. Beberapa keunggulan yang dimiliki oleh produk PHP diantaranya:

1. PHP adalah bahasa pemograman yang open source.

2. PHP memiliki tingkat akses yang lebih cepat.

3. PHP memiliki tingkat lifecycle yang cepat sehingga selalu mengikuti perkembangan teknologi internet.

4. PHP memiliki tingkat keamanan yang tinggi.

5. PHP mampu berjalan di beberapa server yang ada misalnya Apache, Microsoft IIS, PWS, AOLserver, phttpd, fhttpd, dan Xitami. PHP mampu berjalan di Linux sebagai Platform sistem operasi utama bagi hp, namun juga dapat berjalan FreeBSD, Unix, Solaris, Windows, dan yang lainnya.

6. $\quad$ PHP mendukung akses ke beberapa database yang sudah ada, baik yang 
bersifat free/gratis ataupun komersil. Database ini antara lain MySQL, PosgreSQL, mSQL, Informix, dan MicrosoftSQL server.

\subsubsection{MySQL}

MySQL merupakan software open sourceyang bekerja menggunakan bahasa basis data atau DBMS (DatabaseManagement Sistem) yang sangat populer di kalangan pemrograman web.MySQL dikembangkan oleh sebuah perusahaan Swedia bernama MySQLAB, yang kala itu bernama TcX Data Konsult AB, sejak sekitar 1994-1995,meski cikal bakal kodenya bisa disebut sudah ada sejak 1979. Awalnya TcX membuat MySQL pada waktu itu untuk mengembangkan aplikasi Web untukklien - TcX yaitu perusahaan pengembang software dan konsultan database.Kala itu Michael Widenius, atau "Monty", pengembang satu-satunya di TcX,memiliki aplikasi UNIREG dan rutin ISAM yang dibuat sendiri dan sedangmencari antarmuka SQL untuk ditempelkan di atasnya. Mula-mula TcXmemakai mSQL, atau "mini SQL”. (2011:44).

\section{METODOLOGI PENELITIAN}

Penelitian ini menggunakan metode penelitian dan pengembangan pendidikan (Educational Research and Development). Tahap penelitian dan pengembangan ini terdiri atas empat tahap, yang disebut model 4D (define, design, develop, dan disseminate). (Define adalah kegiatan mengumpulkan berbagai informasi yang diperlukan (needs assessment) melalui studi literatur dan studi lapangan untuk menyusun produk awal. Design adalah kegiatan merancang produk awal. Develop adalah kegiatan memvalidasi dan mengembangkan produk sehingga dihasilkan produk yang teruji yang siap diimplementasikan. Disseminate adalah kegiatan menyebarluaskan dan mengimplementasikan produk tanpa kehadiran peneliti. Pada penelitian ini kegiatan yang dilakukan hanya sampai pada tahap develop, meliputi validasi ahli, uji coba terbatas, dan uji coba utama.

\section{HASIL DAN PEMBAHASAN}

Perangkat yang dikembangkan dalam penelitian ini adalah kuesioner mengukur tingkat kepuasan mahasiswa terhadap proses pembelajaran aplikasi berbasis web untuk mengukur tingkat kepuasan mahasiswa terhadap proses pembelajaran.

Implementasi dari hasil pembuatan tugas tentang sistem pakar selanjutnya diimplementasikan dalam bentuk aplikasi yang berbentuk web. Dimana aplikasi ini hanya mengutamakan dari sisi fungsionalitas sajasehingga nantinya masih dapat dikembangkan lebih lanjut.

\section{KESIMPULAN DAN SARAN}

\subsection{Kesimpulan}

Hasil akhir dari kegiatan penelitian pengembangan ini adalah produk sistem pakar mengukur tingkat kepuasan mahasiswa dalam pembelajaran (Studi Kasus: Mahasiswa Teknik Informatika) dan aplikasi berbasis web. Berdasarkan analisa hasil penelitian dan pembahasan dalam laporan ini, maka dapat disimpulkan bahwa:

1. Sistem pakar adalah sistem yang berusaha mengadopsi pengetahuan manusia ke komputer, agar komputer dapat menyelesaikan masalah seperti yang biasa dilakukan oleh para ahli (Kusumadewi, 2003:109);

2. Pengajaran adalah suatu sistem yang terdiri dari komponen-komponen meliputi, tujuan pendidikan, peserta didik, pendidik, bahan atau materi pelajaran, pendekatan dan metode, media atau alat, sumber belajar, evaluasi;

3. Cara untuk mempertahankan dan meningkatkan prestasi dalam bidang akademik di Universitas Majalengka adalah dengan meningkatkan kinerja pendidik dalam pembelajaran terhadap Mahasiswanya;

4. Pengembangan sistem pakar mengukur tingkat kepuasan mahasiswa terhadap proses pembelajaran (Studi Kasus: Mahasiswa Teknik Informatika) dan aplikasi berbasis web dilakukan dengan menggunakan metode penelitian dan pengembangan pendidikan (Educational Research and Development). Tahap penelitian dan pengembangan ini terdiri atas empat tahap, yang disebut model 4D (define, design, develop, dan disseminate). Pengembangan perangkat ini hanya sampai pada tahap develop, 
meliputi validasi ahli, uji coba terbatas, dan uji coba utama;

5. Hasil pengembangan sistem pakar mengukur tingkat kepuasan mahasiswa terhadap proses pembelajaran terdiri dari kuesioner kepuasan mahasiswa sebagai pengukur tingkat kepuasan mahasiswa terhadap proses pembelajaran di Jurusan Teknik Informatika Universitas Majalengka;

Produk perangkat pengukur tingkat kepuasan mahasiswa terhadap proses pembelajaran dan aplikasi berbasis web sudah dapat digunakan bagi mahasiswa Teknik Informatika Universitas Majalengka. Hal itu berdasarkan hasil analisis data validasi ahli dan data uji coba lapangan.

\section{REFERENSI}

Anhar. 2010.Panduan Menguasai PHP dan MySQL Secara Otodidak. Jakarta: Mediakita.

Aribowo, A.S., dkk, Sistem Pakar Dengan Beberapa Knowledge Base menggunakan Probabilitas Bayes Dan Mesin Inferensi forward Chaining, Seminar Nasional Informatika UPN "Veteran" Yogyakarta, 2011.

Hadi,Triono.2013.SistemPakar.Jakarta :http://3 onoikom.wordpress.com/materikuliah/sistem-pakar/.

Margono, Gaguk. 2005. Validitas Konstruk Instrumen Pengukur Tingkat Kepuasan Mahasiswa sebagai Pelanggan Internal. Jurnal PTM. Vol. 5. No. 1. 9 - 18.

Minartiningtyas,ari.2013.MesinInferensi.2012. Denpasar:http://informatika.web.id/mes ininferensi-inference-engine.htm

Minartiningtyas,ari.2013.SistemPakar.Denpasar :http://informatika.web.id/category/kec erdasan- buatan/

Saputra, Agus. 2011. Step by Step Membangun Aplikasi SMS dengan PHP dan MySQL. Jakarta: Elex Media Komputindo.

Sugiyono. 2009. Metode Penelitian Kuantitatif, Kualitatif dan R\&D. Bandung : Alfabeta

Supriyanto, Aji. 2005. Pengantar Teknologi Informasi. Jakarta: Salemba Infotek

Tjiptono, Fandy. 2000. Perspektif Manajemen $\&$ Pemasaran kontemporer.Yogyakarta : ANDI. 